\title{
Indonesia in the Eyes of Medieval Arab Historians and Explorers
}

\author{
Muhammad Luthfi \\ Program of Middle East and Islamic Studies, Universitas Indonesia, \\ Salemba, Central Jakarta, Indonesia
}

\begin{abstract}
Indonesia is known as an archipelago country which has thousands of islands and abundant natural resources which located in a strategic geographical position, located between two continents; Asia and Australia. Therefore, Indonesia became a destination for explorers or become a haven for them. Arab historian who first wrote about Indonesia is Zakariya Al Qazwiny, died Year 682 Hijri or 1284 AD. In his book "Traces of State and Human News" says that one of the areas that is known in the eastern hemisphere is "Jâwah" which is located between China and India. From there that traders bring are Java sandalwood, lime, clove and Chinese medicine. Meanwhile among Arabs explorers who've visit to Indonesia are Ibn Battuta. He came to Indonesia in 1345 AD and paid a visit to the Kingdom Samudra Pasai. Ibn Battuta was said to have transited in Indonesian islands because he was on his journey from India to China, after his visited Sri Lanka and other countries. According to Sartono Kartodirdjo, travel records of the past can be made as one of the sources in historical studies.
\end{abstract}

Keywords: Indonesia, History, and Arab Historian

\section{Introduction}

Indonesia was known as the largest archipelagic states with thousands of islands, abundant natural resources, and amazing natural beauty. Indonesia (Nusantara) has a strategic geographical position, located between the maritime routes of India and China. Therefore, Indonesia often became a transit point or a prominent destination among the explorers.

In the realm of Arabic literature, the first Arabs historian who first mentioned the word "Jâwah" was Zakariya al-Qazweiny (d.628 H / 1283 AD). In his book "States and Human News Footprints" آثـ ار الـــلاد " (و أخبــار الـعبــاد ) Qazweiny mention that one of the "state" (بـادد) that are well known in the eastern hemisphere is "Jâwah", which located between China and India. From that "state" traders bring Javanese Sandalwood, lime (camphor), clove and Chinese medicine (al-Qazweiny, n.d: 29). Among Arabs explorers who have been visited Indonesia is Ibn Battuta, where he came in 1345 AD and arrived in the Kingdom Sumutrah (Samudera Pasai). Ibn Battuta was said to have transited in Indonesian islands because he was on his journey from India to China, after his visited Sri Lanka and other countries (Batuta, n.d.: 617).

In this article, the author will also include the journey of Marco Polo to sharpen the study of Nusantara archipelago, as well as compering the explanation mentioned by Arab historians and exproler, especially Ibn Batuta. According to Kartodirdjo, gathering material from both historian books or travel records is an important step in the study of history (Kartodirdjo, 1992: 9). This explanation lead us to a question: How does Indonesia (Nusantara) was viewed by the Arab historians in a span of hundreds of years during the Medieval Age?

\section{Discussion}

\subsection{Indonesia (Nusantara) in the Medieval Age}

1. Java

According to Arab historians and explorers, there are several names that they used to called some islands in the Indonesian archipelago, in particular two Indonesian islands, Java and Sumatra. The first historian who mention the word "Java" is Zakaria bin Muhammad bin Mahmud al-Qazweiny (d.682 H / 1283 AD), where he explains the word "Jâwah" ( جـا و ة) in a separate section. According to him, "Jâwah" is a country / Bilad (بـا د د) loacated between India and China sea coast. At that time, the merchants from India to China (and vice versa) 
must pass through this country. Traders typically would purchase goods from this country such as Java's Eaglewood, camphor, rice, jewelry, etc. which they would send to various countries (al-Qazweiny, n.d: 29).

The second historian who mentioned the island of Java was Marco Polo (d.1324 AD). In his book entitled "The Travels of Marco Polo" (Komroff, 1953: 154 Chapter 6), particularly on the sixth chapter entitled "of the Island of Java" he stated that there is a large island called "Java", located around 1500 miles from "Ziamba" (Indo China). He stated that according to the navigator who gave him reliable information, Java is the largest island in the world. The island was under the rule of a king who had a tradition of giving tribute (offerings) to the power of another (unseen) and the inhabitants are idolaters. This kingdom is very rich in commodities such as chili, nutmeg, oil, ginger, cloves and various spices and medicines. The traders from the town of Zaitun and Manji (China) imports their goods. There is also a commodity iron in large amounts, as well as various seasonings that are exported to all over the world. It was also mentioned that the Great Khan (Kublai Khan) did not want to take the region under its rule because it was too far and too dangerous in term of its navigation. (Komroff, 1953: 155 Chapter 6).

After that, Marco Polo describes an island smaller that Java (little Java) which he called as "the island of Java minor", and today known as Sumatra island (Komroff, 1953: 155, Chapter 9). According to him, there are 8 kingdoms in this island. Each kingdom has its own language that is different from each other. One of the six kingdoms he visited was the Kingdom of Felech, a kingdom where most of its inhabitants worshipping idols. Furthermore, he mentioned that on the coast side, there are communities that have converted to Islam because of the meritorious of Arab traders called Saracen (Komroff, 1953: 155 Chapter 9). According to the researchers, Kingdom Felech is Perlak Sultanate, a sultanate that was established before Samudera Pasai. In Hikayat RajaRaja Pasai, as cited by Hoesein Djajadiningrat, he mentioned that the first Sultan of Samudera Pasai is al Malik al-Saleh who died in 1297. He added that Sultan al Malik Saleh was married to the daughter of Perlak Sultanate and they have a son named Al Malik al-Zahir (Djajadiningrat in Soedjatmoko, 2007: 75).

If the Kingdom of Felech as mentioned by Marco Polo is Perlak Kingdom, Marco Polo will mention that the kingdom is Islamic kingdom, because Marco Polo arrived at Sumatra around the year 1285, in which the Sultanate Perlak had been established. But Marco Polo stated that majority of the people in Felech are idolaters, he said that "its inhabitants are more the most part idolater", although he also stated that part of the coastal zone pepulation have converted to Islam in favor of Arab traders that Marco Polo called the group as "Saracen Traders" (Komroff, 1953: 155 Chapter 9).

The third historian who mentions the word "Java" is Ibn Battuta in his book "Rihlah Ibn Battuta". He visited Java (Sumatra) in 1342 AD (Batuta, n.d: 531). He mentioned that after traveling for 25 days, he arrived at Java, an island that famous for its Javanese incense. Ibn Battuta described this island as a charming green island, trees comprised mainly of palm trees, clove, Indian aloes wood, and camphor. After going down in the harbor, he was

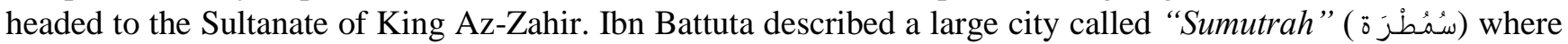
the city was surrounded by the castle of wood and wooden towers. (Batuta, n.d: 617). They were using China's currency of copper and gold to trade. But the coins are not printed (Batuta, n.d: 617-19).

Thus, according to Ibn Battuta, Java is the island of Sumatra. While the "Sumatra" is the name of the city in which the sultanate was lead by Sultan Az-Zahir. Historically, Sultan Malik az-Zahir is the sultan of the Islamic Kingdom of Samudera Pasai, which was established in 1267 with its first king Malikus Sultan Saleh. Ricklefs mentioned that the tomb of Sultan Malikus Saleh was found and he was died in 1297 AD (Ricklefs, 2001: 4). As for King az-Zahir that was mentioned by Ibn Battuta is Sultan Mahmud Malik az-Zahir II that came into power in 1330 -1349. While Ibn Battuta mentions that the Sultan Al-Zahir, who he visited in Sumatra is a Muslim Shafi'i, honoring the scholars, very humble and loves to do jihad. It added that the Sultanate society adopting the school of thought of Shafi'i (Batuta, n.d: 618).

\section{Al-Ramy island; al-Ramin island; Ramny island; Kalah island and Barly island}

In addition to Java, there are several names that possibly refer to the island of Sumatra in nowdays. Ibn

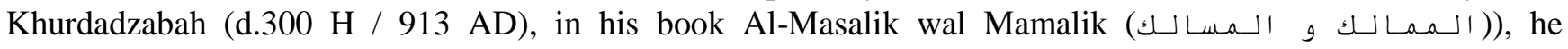

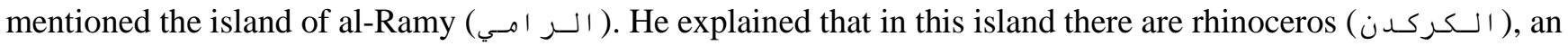
animal that smaller than elephants and greater than buffalo, graze and ruminate as cows and goats. On the same page he mentioned the Mountains "Zabij". He said that on the mountain there is a big snake that able to eat an elephant (Hurdadzabah, tt.: 18). He described the conditions of al-Râmy islands (Sumatra island) as an island 
where its people has no clothes on (still bare), using a language that he did not understand, their har was smooth and red in color, they phsicial appearance was small but brave. They are really good at climbing trees and hanging with their hands (Khurdadzabah, nd: 18). Al-Qazweiny describes people on the island "Java" (Sumatra) and the island of "al-Ramany" (Sumatra) as described by Ibn Khurdadzabah adding that the locals has 4 syibr (inch) in height (al-Qazweiny, n.d: 29).

Furthermore, Ibn Khurdadzabah also mentioned King Zabij (مــك الـز ابـج), which referred to the Overlord ( الـمــر اج). Most likely what Khurdadzabah mean with "Zabij" is the kingdom of Srivijaya. Pusponegoro stated in his book "the Indonesian National History volume II" that "the Arabs recording the Kingdom of Srivijaya (Sumatra) in their sources under the name of "Zabag" (Poesponegoro, 1993: 67).

While al-Mas'udi (d. 346 AH / 957 AD) in his book "Murujud Zahab Wa Ma'adinul Jauhar" mentions another name for the island of Sumatra which is quite similar with the records of Ibn Khurdadzabah. He said that within 1000 farsakh (miles) from the island of Serendib (سرنـديـب) or Sri Lanka, there is an island known by the name of al-Ramin (الـر امـين ). The island is inhabited and there were several kingdoms in it, there are also many gold mines. On the island, there is also a "state" Qansur (قـنصو ر) which is famous for its al-Qanshuri camphor. Most likely that "Qansur" is the miss-spelling of the Fanshur that was famous for its camphor which located on the west coast of Sumatra. Al-Mas'udi also described that the island has lots of lightning, thunder and earthquakes, while the staple food of its population are coconut. The island produces wood, rattan, gold, and also known for its elephants. Some of the population in this island still eat human flesh. (Al-Mas'udi, n.d .: 118-119). While Al-Qazweiny call the island by the name of al-Ramani ( الـــــ (Al-Qazweiny, tt: 29), and explained that there are animals such as rhinoceros, buffalo, camphor trees, rattan, and so on.

Al-Ansari (d. 727 AH / 1327 AD) also mentioned in his book "Nukhbatud Dahr fi 'Ajâib al Bar wal Bahr")

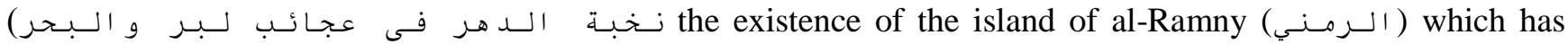
characteristics that are similar to the description of the previous historians. He was also mentioned that the island produces al-luban al-Jawi or Javanese incense (Al-Ansari, tt: 153). On another page, al-Ansari mentioned the island of Kalah (ك) (كــ). On this island, exist the city of Fansur and Jawah. Presumably that Kalah is another name for the island of Sumatra, because other historians mentioned the two cities was located in Sumatra (al-Ansari, n.d: 153 ).

Furthermore, Muhammad bin Abdul Moneim al-Himyari in his book "Al-Raudh al-Mi'thar fi Khabar alAqthar" (الـروض الـمعطـار في خبـر الأقطـار ) (d. 900 AH / 1495 AD) mentioned another name for the

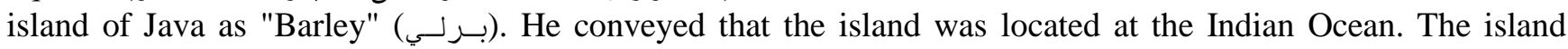
produce camphor that being exported to China. He added that beside this island, there was 6,000 islands more. From this description, it can be concluded that Sumatra island not only called as Java, but also called by the name of al-Râmin, al-Râmany, al-Ramny, Kalah and Barli.

\section{The Greatness of the Sultanates (Samudera Pasai)}

In his book, Ibn Battuta thought that the people were so friendly to the guests. When he and his entourage arrived at the harbor, several small boats that carry coconuts, bananas, grapes and fish were coming by. According to local residents, it was their habit to give foods to the new comers (especially traders) who visit their island in order to get smaller reward in return (Batuta, n.d: 618).

In receiving sultanate's guests, they will first checking the ships of the guests. This inspection was done by Bandar Port (Pelabuhan Bandar). After the ship was inspected, the entire group was asked to get off the ship and they were taken to the resort. Furthermore, the Vice Bandar will send a letter to the King to inform him about the arrival of a group. This initial process ad reception was conducted when Sultan az-Zahir in throne, upon the arrival of Ibn Battuta in 1343 AD. In the next process, Sultan will sent a group to welcoming the guests (Batuta, n.d: 618). Some scholars on the group was Prince Daulasah, (دولـسة ), a judge, Prince Sayyed AsSairozy, Prince Tajudin al-fiqh Asbihany and several other Islamic Law experts. Looking at the family name of the two scholars, most likely they were not locals but from Iran, which refer to the city of Siraz and Isfahan. This means that the empire of az-Zahir already have relations with various countries, including with West Asian scholars. Then, Ibn Battuta and his entourage headed to the Sultanate by using vechiles, which located 4 miles from the port.

When it reached the Sultanate, the delegation was asked to enter the Sultanate by descending from the vehicle and then entering the building by walking. The hospitality was also felt by Ibn Battuta in the process of 
meeting with the Sultan. They was received by the Vice Sultan as the head of household of the Sultanate. He also arranged a meeting with the Sultan. Ibn Battuta and his entourage were taken to the place of rest, which is a wooden house surrounded by gardens and wait there for 3 days. The house is also equipped with a bed made from rattan, covered by beautiful silk, and served by male and female waiters. According to Vice Sultan, every guests who will meet with the Sultan should rest for 3 days so they would be on their fit condition and feel refreshed. Ibn Battuta describes the kindness and hospitality of the Sultan in the sub-chapter entitled "The Story to the Sultanate and Sultan's Kindness" (Batuta, n.d: 618).

Sultan's humility can be seen in his presence at the Jumu'ah assembly and dialogue after the Friday prayers which was led by the Chief of Justice Prince Sayyid Al-Sairazy. This assembly discusses fiqh law in the context of Shafi'i school of thought and then continue with dialogue that sometimes criticized the policies of the Sultan. Sultan comes by wearing atributes like the scholars of Fiqh would wear, he did not wear a formal dress for a Sultan. At that time, Ibn Battuta was welcomed by the Sultan and seated beside the Sultan (Batuta, n.d: 619). After the Friday assembly, Sultan entered into a booth and changed his clothes into a formal clothes that shows his greatness. Then he leaved the masjid, heading to the Sultanate and he was welcomed by ministers and other officials of the Sultanate.

The greatness of the Sultanate can be seen from the accompaniment procession of Sultan from the masjid to the palace. As narrated by Ibn Battuta, when the Sultan coming out of the masjid, he leaves the masjid toward the Sultanate palace by wearing a formal dress that shows his greatness. The Sultan was welcomed by ministers, princes, secretary of state, state officials, the scholars, poets and military officials. All of them sequentially greeted the Sultan. After greeting the Sultan, they're going back to their respective places. The Sultan would ride an elephant with 50 elephants and 100 horses on his right and left side. A dance was then performed afterwards, using horses that has gold ornaments as its decoration. Ibn Battuta said that he ever seen such performances when he was in the presence of Sultan Muhammad in India (Batuta, n.d: 620).

According to Ibn Battuta, in terms of greatness and power, this Sultanate was smaller than the India Sultanate which he used to visit. He apprehend that fact from the words of Sultan's representative after he served him with a variety of food, he says: "Sultan said that we could only serve this, it may not similar to those served by Sultan Mohammad of India. The words of Sultan's representative can be interpreted that this sultanate was not as big as India Sultanate, and this Sultanate cannot serving foods as fancy as those served under the commad of Sultan Muhammad in India (Batuta, n.d: 620). Ibn Battuta have known the Sultan's representatives before, when both of them visited Sultan Muhammad in India (Batutah, n.d: 620).

Ibn Battuta's first visit to the archipelago shows the relationship between Islam and the archipelago. Historical events written in the record journey of Ibn Battuta describes that Islamic teaching has been embraced by some people in Sumatra at the time. The existence of the Sultanate of Samudera Pasai was reinforced by the written evidence - Arabic writing in the tombs of the ancient kings in Sumatra were engraved with Arabic script. The historians also found an Arabic manuscript of the Sultanate of Samudera Pasai which was shown to the Portuguese empire dated on $16^{\text {th }}$ century AD (Lambourn, 2004:212; Lambourn, 2008:258). This indicates that the Sultanate has used Arabic as the official language of the sultanante. Ibn Battuta records also show that he had no difficulty in communicating with the public sultanate which is most of them can speak Arabic. Although Ibn Battuta just a short layover in Indonesia, his record proves that Islam has existed since the $11^{\text {th }}$ century $\mathrm{AD}$ in the archipelago.

\section{Conclusion}

From the above explanations, it can be concluded that the history of Nusantara in the medieval age needs more observation and studied carefully. This study found that the first Arab historians who mentioned the word "Java" is al Qazweiny (d. 682 H / 1283 AD). He mentioned that "Java" is a country / Bilad (بـ) that lies between India and China. On his journey, Marco Polo also arrived at "Java" island which is the true Java island that we know today. However, Marco Polo recorded Sumatra island that we know today as "Small Java or Minor Java". On the other hand, Ibn Battuta recorded in his book that Java island that we know today as the island of Sumatra. Ibn Battuta refer the word "Sumatra" to the name of a town in Sumatra in which the Kingdom of Pasai was located. Beside the "Java", several names was being used to call Sumatra island, namely: the island of alRâmin, al-Râmany, al-Ramny, Kalah and Barli. 
In the 13th century, particularly during Marco Polo's journey to the island of Java and Sumatra, he did not find any Islamic kingdom. He only find out that some people who reside at the coastal side of Sumatra have followed the religion of Muhammad (PBUH) or Islam. In fact, Islamic Kingdom has been established in Sumatra in the 13th century or earlier, namely the Kingdom of Perlak and the Kingdom of Samudera Pasai.

In the context of Indonesian history, the history of Perlak Sultanate and Samudera Pasai did not received appropriate attention. Marwati Djoened and Nugroho Notosusanto in their book "Indonesian National History" does not address both sultanates. Meanwhile, on his explanation about Islamic Kingdoms before the Dutch occupation, Badri Yatim start with "the Kingdom of Samudera Pasai" instead of "the Kingdom of Perlak" which has exist before the establishment of the Samudera Pasai Sultanate.

\section{Bibliography}

[1] Al-Anshari, "Nukhbatud Dahr fi 'Ajâib al Bar wal Bahr”, (نخبة الدهر فى عجائب لبر والبحر). Batenburg, Netherlands,1865. Pp. 189.

[2] Al-Faqih, Ibnu, “Mukhtashor Kitabul Buldan”. (مختصر كتاب البلدان) Leiden: Brill Company, 1302.

[3] Al-Himyari, Muhammad, "Al-Raudh al-Mi'thar fi Khabar al-Aqthar",

1. الروض المعطار فى خبر الأقطار), Maktabah, Libanon, 1995.

[4] Al-Mas'udi, "Murujud Dzahab Wa Ma'adinul Jauhar", (مروج الذهب و معادن الجوهر). Al-Maktabah al-“Ashriyah, Beirut, 2005, pp. 118-119.

[5] Al-Qazweiny, Zakaria, n.d. "Ātsarul Bilâd wa Akhbârul 'Ibâd”, (آثار البلاد وأخبار العباد). Dar al-Shadir, Beirut.

[6] Batutah, Ibnu, n.d, "Rihlah Ibnu Batutah”. (رحلة ابن بطوطة) Beirut: Dar al-Fikr.

[7] Batutah, Ibnu, "Rihlah Ibnu Batutah”, (رحلة ابن بطوطة) ), (رطة بن Pustaka Al Kautsar, Jakarta, 2009.

[8] Gallop, Annabel Teh. A Jawi Sourcebook for the Study of Malay Paleography and Orthography, Journal of Indonesia and the Malay World, Vol. 43, No. 125, pp. 13-171, Routledge: Taylor \& Francis Group, 2015.

[9] Kartodirdjo, Sartono, “Social Science Approaches in Research History's Methodology'. PT Gramedia Pustaka Utama, Jakarta, 1992, pp. 9.

[10] Khurdadzabah, Ibnu, “Al-Masalik wal Mamalik” (المسالك و الممالك), Brill, Leiden, 1873,,

[11] Komroff, Manuel, n.d., The Travels of Marco Polo. New York: The Maple-Vail,n Book Manufacturing Group, ch. 6, pp. 154-155.

[12] Lambourn, Elizabeth. The Formation of the Batu Aceh Tradition in Fifteenth-Century Samudera-Pasai, Journal of Indonesia and the Malay World, Vol. 32, No. 93, pp. 211-248, Carfax Publishing: Taylor \& Francis Group, 2004, pp. 212.

[13] Lambourn, Elizabeth. Tombstones, Texts, and Typologies: Seeing Sources for the Early History of Islam in Southeast Asia, Journal of the Economic and Social History of the Orient, Vol. 51, No. 2, pp. 252-286, Published by: Brill, 2008, pp. 258.

[14] Peacock, A.C.S. Three Arabic Letters from North Sumatra of the Sixteenth and Seventeenth Centuries, Journal of Indonesia and the Malay World, 2016.

[15] Poesponegoro and Notosusanto, Indonesian National History, Balai Pustaka. Jakarta, 1993, pp. 67.

[16] Ricklefs, A History of Modern Indonesia since c. 1200: Creative Print \& Design Ltd, (Wales), Britain, 2001, pp. 4.

[17] Soedjatmoko, "The Introduction to Indonesian Historiography", Cornell University Press, United States, 2007, pp. 75.

[18] Yatim, Badri, "History of Islamic Civilization”, Raja Grafindo Persada, Jakarta, 2009. 